\title{
Evaluation of Interleukin 6 and high sensitive C-reactive protein in relation with Body Mass Index Zaid Nabeel Elia $(\mathrm{MSc})^{1}$ and Nisreen Waleed Mustafa $(\mathrm{PhD})^{2}$
}

\begin{abstract}
Background:Obesity is one of the largest public health problem worldwide. It is a multifactorial chronic disease that increases mortality and the prevalence of heart-related diseases. Adipose tissue secretes large numbers of peptides that resemble cytokines. Interleukin 6 )IL6 ( is one of those peptides that are released by adipose tissue. One of the major function of IL-6 is sending signal to liver to secrete C-reactive protein (CRP).

Objective:To study the relationship between obesity and inflammation by: estimation of high sensitive C-reactive protein (hsCRP) and IL-6 concentrations in participants sera in relation with different body mass indices (BMI).

Patients and Methods: This cross-sectional study was performed through the period of 3 months and 90 participants with the average range of age 25-40 years old were included, they were categorized into three groups ( 30 with BMI less than 25, 30 with BMI ranged between 25-29.9 and 30 with BMI more than 30).

Results:The concentrations mean of hsCRP was significantly elevated among the three studied groups as a result of BMI increasing $(0.945 \mathrm{mg} / \mathrm{L}, 1.694 \mathrm{mg} / \mathrm{L}$ and $2.521 \mathrm{mg} / \mathrm{L}$ respectively). There was a significant increasing in the mean of IL-6 in relation with increased BMI in all included groups $(1.084 \mathrm{mg} / \mathrm{L}, 1.802 \mathrm{mg} / \mathrm{L}$ and $3.531 \mathrm{mg} / \mathrm{L}$ respectively). Linear correlation between the concentrations means of hsCRP and IL-6 were found in all studied groups.

Conclusion:This study demonstrated a significant relationship between obesity and inflammatory marker (IL6 and hsCRP) .

Key words: Obesity, inflammation, hsCRP, IL-6, BMI.

Corresponding Author: nisrenw@yahoo.com

Received: $26^{\text {th }}$ October 2017

Accepted: $6^{\text {th }}$ December 2017

https://doi.org/10.26505/DJM

${ }^{1}$ Medical Laboratory Technology Department-Erbil Technical Health College- Erbil Polytechnic University- Erbil - Iraq.

${ }^{2}$ College of Pharmacy- Basrah University - Basrah - Iraq.
\end{abstract}

\section{Introduction}

Obesity is a chronic disease that develops from the interaction of behavioral, metabolic and psychological and molecular factors. It is caused by adipose tissue increasing and results in excessive fat accumulation Fernández-Sánchez et al., 2011.

Obesity is considered the largest public health problem especially in industrialized countries ( Fried et al., 1998 ) . Obesity increases the rate of mortality and the prevalence of diabetes, cardiovascular diseases and colon cancer (Bustard et al.,2002).

Large numbers of physiologically active peptides are secreted by adipose tissues called adipocytokines because of the related properties with cytokines. Leptin, IL-6 , tumor necrosis factor-alpha (TNF-a), 
plasminogen activator inhibitor 1 , adiponectin and others are some of these adipocytokines (Alikaşifoğlu et al., 2009).

IL-6 is produced by many cell types such as monocytes, fibroblasts and endothelial cells and many tissues including adipose tissue. The production of IL-6 by adipose tissue is induced in obesity (Fried et al., 1998 ; Bustard et al.,2002). It is concept that $15-30 \%$ of circulating IL-6 levels produces from adipose tissue in absence of acute inflammation (Mohamed-Ali et al.,1997).

One of the main IL-6 effects is the stimulation of hepatic CRP production which is an independent major marker of cardiovascular complications (Ridker , 2003) Also IL-6 play a central role in the association of obesity and inflammation (Yudkin et al.,2000). IL-6 level in adipose tissue is strongly correlated with circulating CRP and IL-6 levels (Maachi et al., 2004).

\section{Patients and Methods}

A total of 90 participants were selected from Irbil city. They were all men and aged from 25-40 years old. According to BMI they were categorized into three groups. 30 participants had BMI less than (25), 30 other participants had BMI ranging between (2529.9), and finally 30 participants above (30).
IL-6 and hsCRP were measured for all samples included in this study. Serum hsCRP levels were estimated using spectrophotometric method (Biosystems S.A., Spain) . Serum IL-6 concentrations were measured using Enzyme immunoassay ELISA kit ( Beckman Coulter, France). Patients had a history of inflammation diseases and hormonal or drug therapy at the time of study were excluded .

\section{Statistical Analysis}

Spss program was used for statistical analysis and statistical difference was accepted at $p \leq 0.05$. One-way ANOVA test was used to compare between concentration means of hsCRP and IL-6 for the three groups of BMI. The correlation was analyzed with Pearson correlation coefficient to assess the relative strength of association of hsCRP and IL-6. Descriptive statistics were generated for all variables.

\section{Results}

The results of hsCRP concentrations for the three groups showed that there are a significant differences $(p \leq 0.05)$ among groups according to BMI. Table (1) Shows the result of statistical analysis for hsCRP of three groups of BMI, where hsCRP concentration raised as a result of $\mathrm{BMI}$ increasing . Also figure (1) shows the relationship between hsCRP and BMI.

Table (1): hsCRP level of participants serum.

\begin{tabular}{||c||c||c||c||c|c||}
\hline Groups & Number & Range $\mathrm{mg} / \mathrm{L}$ & Mean $\mathrm{mg} / \mathrm{L}$ & SD & SE \\
\hline \hline BMI $<25$ & 30 & $0.22-2.7$ & 0.945 & 0.692 & 0.089 \\
\hline \hline BMI $=25-29.9$ & 30 & $0.77-3.2$ & 1.694 & 0.555 & 0.071 \\
\hline \hline BMI $\geq 30$ & 30 & $1.77-3.4$ & 2.521 & 0.432 & 0.064 \\
\hline
\end{tabular}




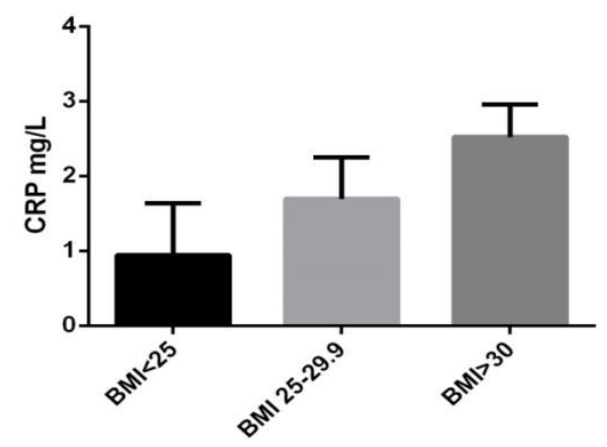

Figure (1): The relationship between hsCRP concentrations and BMI

Data analysis of IL-6 concentrations result revealed that means of IL-6 in the three groups of BMI were significantly different $(p \leq 0.05)$. IL-6 level in third group was higher than second group of BMI and second group was higher than first group of BMI , table (2). Figure (2) shows the relationship between IL-6 and BMI.

Table (2): IL-6 level of participants serum.

\begin{tabular}{|c||c||c|c||c||c||}
\hline Groups & Number & $\begin{array}{c}\text { Range } \\
\mathrm{pg} / \mathrm{ml}\end{array}$ & $\begin{array}{c}\text { Mean } \\
\mathrm{pg} / \mathrm{ml}\end{array}$ & SD & SE \\
\hline \hline BMI $<25$ & 30 & $0.62-2.06$ & 1.084 & 0.316 & 0.040 \\
\hline \hline BMI $=25-29.9$ & 30 & $1.07-2.57$ & 1.802 & 0.387 & 0.050 \\
\hline BMI $\geq 30$ & 30 & $2.00-4.99$ & 3.531 & 0.775 & 0.100 \\
\hline
\end{tabular}

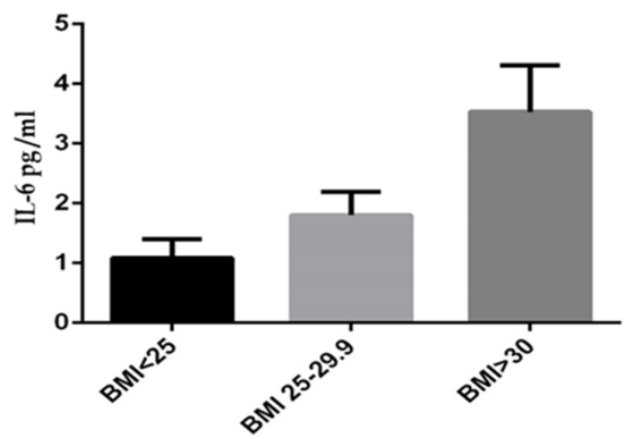

Figure(2): The relationship between IL-6 concentration and BMI.

Levels of hsCRP were positively the correlation coefficient $(r=0.677$, correlated with IL-6 levels according to $\quad \mathrm{p}=0.000$ ), figure (3). 


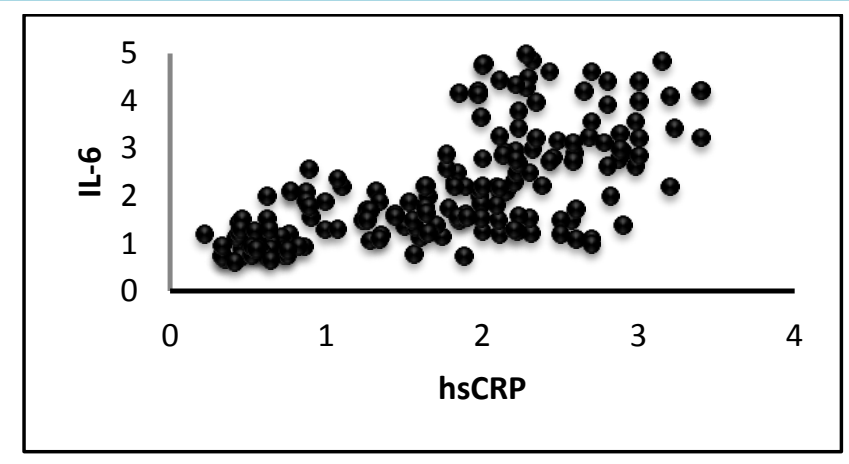

Figure (3): Correlation between serum level of hsCRP and IL-6 in participants sera.

\section{Discussion}

Immunity and metabolism are two main systems for survival and are closely associated with each other. Obesity are linked with immune activation and caused inflammation while malnutrition lead to immunosuppression (Wellen and Hotamisligil 2005), from this theory the present study was designed to examine the relationship between obesity and inflammation. Two of high sensitive inflammatory markers were chosen to analyzed collected sera samples which were hsCRP and IL-6, samples were categorized into three groups according to the BMI.

Excess body fat is linked to increased mortality and morbidity by effecting the development of diseases as diabetes type II and cardiovascular disease . Chronic inflammation in adipose tissue may be a mediator of diseases associated with obesity. Pro-inflammatory cytokines influence adipose tissue function and could cause metabolic disorders. Also circulating cytokines concentrations may be increased in obesity (Alvehus,2012). Over the world, more than 1 billion adults are overweight, 300 million of whom are having a BMI equal to or greater than $30 \mathrm{~kg} \mathrm{~m}-2$ (WHO,2002).

In this study, hsCRP levels were found to be elevated according to increase grade of obesity where the mean of hsCRP in group of $\mathrm{BMI}>30$ recoded highest value (2.521 $\mathrm{mg} / \mathrm{L}$ ) among means of other BMI groups. This elevation gave significant differences $\mathrm{p} \leq 0.05$.Khan et al. (2011)comparison agreed with present study which showed significant difference in CRP and TNF- $\alpha$ levels between individuals with normal weight $(\mathrm{BMI}<30)$ and obese individuals (BMI>30). Choi et al,(2013) concluded that obesity is associated with elevated levels of CRP, also they referred to there was no any association between CRP levels and obesityin male and female children. Dandona et al. (1998) result corresponded with present work they found inflammatory markers such as CRP and TNF- $\alpha$ levels were elevated in obese individuals. Fat cells numbers are completed during childhood and adolescence and remains constant during adulthood in lean and obese individuals. fat mass enlargement 
is due to hypertrophy in adults while weight loss is linked to decrease adipocyte volume (Spalding et al., 2008). This is important because hypertrophic adipocytes are responsible of expression and secretion some cytokines and adipokines (Skurk et al., 2007 ).

Regarding the results of IL-6, it levels were elevated as a result of $\mathrm{BMI}$ increasing where the $\mathrm{BMI} \geq 30$ recorded highest value among other groups. Obese adipocytes are important source of inflammatory cytokines and chemokines such as IL-6, TNF-alpha, monocyte chemoattractant protein-1 and dysregulated production of adiponectin which anti-inflammatory adipokines (Guilherme et al., 2008). IL-6 is a multifunctional cytokine produced by several immune cells and non-immune tissues. IL-6 stimulates the liver to produce of acute-phase proteins such as CRP, which increase 1000fold in acute inflammation and slightly elevated during low grade inflammation (de Ferranti and Mozaffarian ,2008). IL-6 able to modulate immune response, interfere with lipid and glucose metabolism and impairs adipocyte differentiation (Gustafson, 2010). Adipose tissue is an important source of IL-6 therefore the production of IL-6 increases with fat mass, fat is responsible of $30 \%$ of systemic IL-6 levels, approximately (Mohamed-Ali et al., 1997). Another source of IL-6 is skeletal muscle (Pedersen and Febbraio, 2008).

Study of Bastard et al. (2000) and Kern et al., (2001) agreed with present study, they found positive correlation of IL-6 level with
BMI, especially in obese individuals. The exposure of adipose tissue to IL-6 lead to increase lipolysis due to the IL-6 influences on lipid metabolism, (Trujillo et al., 2004). This study referred to positive correlation of CRP and IL-6 levels elevation $(r=0.677)$. Dandona et al. (1998) and Maachi et al., (2004) study resembled with present result , they showed there is a positive association between the levels of IL-6 in adipose tissue and CRP levels in obese individuals. Chemokines have important role in the inflammation process and macrophages recruiting to adipose tissue. (Weisberg et al., 2003).

Macrophages numbers are positively correlated with body mass and adipocyte size. Accumulated macrophages are considered to be responsible of adipose tissue inflammation since they are the main source of pro- inflammatory cytokine production (IL-6 and TNF-alpha) in adipose tissue (Cancello et al., 2005). After weight loss , macrophage infiltration and expression of pro-inflammatory cytokines in adipose tissues are reduced (Po-Shiuan Hsieh ,2011; Bruun et al., 2006; Cancello et al., 2005 ). CD8 $\mathrm{T}$ cells play the important role in recruitment of macrophage into adipose tissue. Large numbers of CD8 $\mathrm{T}$ cells infiltrated into adipose tissue and induced the macrophages accumulation mice. (Nishimura et al., 2009).

\section{Conclusion}

1-There is a proportional relationship between BMI and CRP in men. 
2-There is a proportional relationship between BMI and IL-6 in men.

3-Linear correlation was obtained between hsCRP and IL-6.

4-Obesity induce inflammation in adipose tissues.

\section{Recommendation}

1-Measure the level of serum IL-6 and hsCRP in the athletics.

2-Determine the relationship linked the CRP and BMI with obesity in women.

3-Study the ability of obesity therapy by immune response modulation.

4-Study the relationship between CD8 T cells and obesity.

5-Comparison study of serum IL-6 and hsCRP levels between male and female groups according to BMI.

\section{References}

[1] Alikaşifoğlu,A.; Gönç,E.; Özön,Z.; Şen, Y. and Kandemir, N. (2009). The Relationship Between Serum Adiponectin, Tumor Necrosis Factor-Alpha, Leptin Levels and Insulin Sensitivity in Childhood and Adolescent Obesity: Adiponectin is a Marker of Metabolic Syndrome. J Clin Res Pediatr Endocrinol. , 1(5): 233-239.

[2] Alvehus, M. (2011). Obesity-associated Inflammation in Adipose Tissue Department of Public Health and Clinical Medicine, Umeå 2012.

[3] Bastard, J.; Jardel, C.; Bruckert, E.; Blondy, P.; Capeau, J.; Laville, M.; Vidal, H. and Hainque, B. (2000). Elevated levels of interleukin 6 are reduced in serum and subcutaneous adipose tissue of obese women after weight loss. J Clin Endocrinol Metab., 85:3338-3342.

[4] Bruun, J.M.; Helge, J.W.; Richelsen, B. and Stallknecht, B. (2006). Diet and exercise reduce lowgrade inflammation and macrophage infiltration in adipose tissue but not in skeletal muscle in severely obese subjects. American Journal of Physiology Endocrinology and Metabolism, 290(5): 961967.

[5] Bustard, J.; Maachi, M.; Van Nhieu, J.; Jardel, C.; Bruckert, E.; Grimaldi, A.; Robert ,J.; Capeau, J. and Hainque, B. (2002). Adipose tissue IL-6 content correlates with resistance to insulin activation of glucose uptake both in vivo and in vitro. $\mathrm{J}$ Clin Endocrinol Metab. , 87(5):2084-2089.

[6] Cancello, R.; Henegar, C.; Viguerie, N.; Taleb, S.; Poitou, C.; Rouault, C.; Coupaye, M.; Pelloux, V.; Hugol, D.; Bouillot, J.L.; Bouloumié, A.; Barbatelli, G.; Cinti, S.; Svensson, P.A.; Barsh, G.S.; Zucker, J.D.; Basdevant, A.; Langin, D. and Clément, K. (2005). Reduction of macrophage infiltration and chemoattractant gene expression changes in white adipose tissue of morbidly obese subjects after surgery-induced weight loss. Diabetes, 54(8): 2277-2286.

[7] Choi, J.; Joseph, L. and Pilote, L. (2013). Etiology and Pathophysiology/Obesity Comorbidities Obesity and C-reactive protein in various populations: a systematic review and meta-analysis. International Association for the Study of Obesity, 14: 232-244. 
[8] Dandona, P. ; Weinstock, R. ; Thusu, K. ; Abdel-Rahman, E. ; Aljada, A.; Wadden, T. (1998). Tumor necrosis factor-alpha in sera of obese patients: fall with weight loss. J Clin Endocrinol Metab; 83:2907-2910.

[9] De Ferranti, S. and Mozaffarian, D. (2008). The perfect storm: Obesity, adipocyte dysfunction, and metabolic consequences. Clin Chem., 54:945-955.

[10] Fernández-Sánchez, A.; MadrigalSantillán, E.; Bautista, M.; Esquivel-Soto,J.; Morales-González, A.; EsquivelChirino,C.;Durante-Montiel,I.;SánchezRivera,G.; Valadez-Vega.C and MoralesGonzález,J. (2011). Inflammation, Oxidative Stress, and Obesity. Int. J. Mol. Sci. , 12(5): 3117-3132.

[11] Fried, S.; Bunkin, D. and Greenberg, A. (1998). Omental and subcutaneous adipose tissues of obese subjects release interleukin6: depot difference and regulation by glucocorticoid. J Clin Endocrinol Metab. , 83(3):847-850.

[12] Guilherme, A.; Virbasius, J.; Puri, V. and Czech, M. (2008). Adipocyte dysfunctions linking obesity to insulin resistance and type 2 diabetes. Nature Reviews Molecular Cell Biology, 9(5): 367377.

[13] Gustafson, B. (2010). Adipose tissue, inflammation and atherosclerosis. J Atheroscler Thromb., 17:332-341.

[14] Hausman, D.; DiGirolamo, M.; Bartness, T.; Hausman, G. and Martin, R. (2001). The biology of white adipocyte proliferation. Obes Rev., 2:239-254.
[15] Kern, P.A.; Ranganathan, S.; Li, C.; Wood, L. and Ranganathan, G. (2001). Adipose tissue tumor necrosis factor and interleukin-6 expression in human obesity and insulin resistance. American Journal of Physiology - Endocrinology and Metabolism, 280(5): 745-751.

[16] Khan, R.; Haque, S.and Quaiser, S. (2011). The inflammatory markers: CReactive Protein and TNF- $\alpha$ predict Cardiovascular risks in obese North Indian subjects . Biomedical Research, 22 (4): 475480.

[17] Maachi, M.; Piéroni, L.; Bruckert, E.; Jardel, C.; Fellahi, S.; Hainque, B.; Capeau, J.; Bastard, J.P. (2004). Systemic low-grade inflammation is related to both circulating and adipose tissue TNFalpha, leptin and IL-6 levels in obese women. International Journal of Obesity and Related Metabolic Disorders, 28(8): 993-997.

[18] Maachi,M.; Piéroni, L.; Bruckert, E.; Jardel,C.; Fellahi, S.; Hainque, B.; Capeau, J. and Bastard, J. (2004). Systemic low-grade inflammation is related to both circulating and adipose tissue TNF , leptin and IL-6 levels in obese women. International Journal of Obesity , 28:993-997.

[19] Mohamed-Ali, V.; .Goodrick, S.; Rawesh, A.; Katz, D.; Miles, J.; Yudkin J.; Klein, S. and Coppack S. (1997). Subcutaneous adipose tissue releases interleukin-6, but not tumor necrosis factoralpha, in vivo. J Clin Endocrinol Metab. , 82(12):4196-4200.

[20] Nishimura, S.; Manabe, I.; Nagasaki, M.; Eto, K.; Yamashita, H.; Ohsugi, M.; 
Otsu, M.; Hara, K.; Ueki, K.; Sugiura, S.; Yoshimura, K.; Kadowaki, T.and Nagai, R. (2009). CD8+ effector T cells contribute to macrophage recruitment and adipose tissue inflammation in obesity. Nature Medicine, 15(8): 914-920.

[21] Pedersen, B. and Febbraio M. (2008). Muscle as an endocrine organ: Focus on muscle-derived interleukin-6. Physiol Rev. ,88:1379-1406.

[22] Po-Shiuan Hsieh (2011). ObesityInduced Adipose Tissue Inflammation and Insulin Resistance, Role of the Adipocyte in Development of Type 2 Diabetes, Dr. Colleen Croniger (Ed.), InTech,China ,P:199.

[23] Skurk, T.; Alberti-Huber, C.; Herder, C. and Hauner, H. (2007). Relationship between adipocyte size and adipokine expression and secretion. J Clin Endocrinol Metab., 92:1023-1033.

[24] Spalding, K.; Arner, E.; Westermark, P.; Bernard, S.; Buchholz, B.; Bergmann, O.; Blomqvist, L.; Hoffstedt, J.; Naslund, E.; Britton, T.; Concha, H.; Hassan, M.; Ryden, M.; Frisen, J.and Arner, P.(2008). Dynamics of fat cell turnover in humans. Nature, 453:783-787.

[25] Trujillo, M.; Sullivan, S.; Harten, I.; Schneider, S.; Greenberg, A. and Fried, S.(2004). Interleukin-6 regulates human adipose tissue lipid metabolism and leptin production in vitro. $\mathrm{J}$ Clin Endocrinol Metab., 89:5577-5582.

[26] Weisberg , S.; McCann, D.; Desai, M.; Rosenbaum, M.; Leibel, R. and Ferrante, J. (2003). Obesity is associated with macrophage accumulation in adipose tissue. J Clin Invest., 112:1796-1808.

[27] Wellen, K. and Hotamisligil G.(2005). Inflammation, stress, and diabetes. J Clin Invest., 115:1111-1119.

[28] World Health Organization . (2002). The World Health Report . Reducing Risks, Promoting Healthy Life, Geneva.

[29] Yudkin, J.; Kumari, M.; Humphries, S. and Mohamed-Ali, V. (2000). Inflammation, obesity, stress and coronary heart disease: is interleukin-6 the link? Atherosclerosis, 148(2):209-214. 